\title{
Analysis of Determinants Accountability for Regional Financial Management in the Regional Government of North Nias Regency
}

\author{
Srinita Hulu ${ }^{1)^{*}}$, Azhar Maksum²), Azizul Kholis ${ }^{3),}$ Tri Hartati Sukartini Hulu ${ }^{4)}$ Christianity Baene ${ }^{5)}$ \\ 1), 2),3),4),5) Departement of Accounting, Faculty of Economics and Business, Universitas Sumatera Utara, Medan, Indonesia
}

\begin{abstract}
This study aims to analyze the effect of financial statement presentation, financial report accessibility, value for money, internal control systems, and leadership styles on the accountability of regional financial management in North Nias Regency's local government. This study used a quantitative analytic survey method by distributing questionnaires to the structural staff at OPD (Regional Apparatus Organization) North Nias Regency. The population is structural employees in 31 OPDs consisting of the Head of OPD, Secretary of OPD, Head of Finance at OPD, and those who carry out accounting / financial administration functions (112 people). Data were analyzed using Descriptive Statistical Analysis and Partial Least Square Analysis (SEM-PLS) with the Smart PLS 3.0 software program. The results showed that the accessibility of financial statements, value for money, internal control systems, and leadership style influenced regional financial management's accountability. The presentation of financial statements does not affect the accountability of local financial management.
\end{abstract}

Keywords:- Presentation, Accessibility, Value For Money, Internal Control System, Leadership Style, Accountability.

\section{INTRODUCTION}

The phenomenon that can be observed in the development of the public sector today is the growing demand for public accountability by public sector organizations, such as central and regional governments, government work units, departments, and state institutions. The demand for public sector accountability is related to the need for transparency and information provision to the public to fulfill public rights. It states in Law No. 28 of 1999 concerning the Administration of a State that is Clean and Free from Corruption, Collusion, and Nepotism that accountability is one of several principles that must be fulfilled by the government, including local governments.

The government's role in managing regional finances is a form of service to the public by presenting accountable financial reports, providing financial information openly, and providing supervision in the financial management process to produce accountable financial management. It follows the stewardship theory, namely the government's task of presenting financial reports, giving accessibility to financial statements, and the internal control system as a form of service to the public.
Regarding the accountability of regional financial management in North Nias Regency for the 2017 fiscal year, Number: 63.C / LHP / XVIII.MDN / 06/2018 dated 27 June 2018, BPK RI (Supreme Audit Agency of the Republic of Indonesia) found 36 cases of non-compliance, fraud in testing compliance with laws and regulations, and weaknesses in the internal control system in the North Nias Regency Government. Based on the report on the results of the BPK RI examination of LKPD for the 2014-2018 Fiscal Year, the local government of North Nias Regency still received the title of Fair With Exception (WDP)

Accessibility in financial reports is the ease with which a person can obtain financial statement information. The existence of the North Nias Regency government website, namely http://niasutarakab.go.id/, is one of the efforts to increase government accountability in North Nias Regency. However, there are still many essential data that cannot be accessed.

Value for money is a management concept for public sector organizations based on three main elements, namely economy, efficiency, and effectiveness. This concept can be used to measure the achievement of public accountability and good public sector performance.

\begin{tabular}{|c|c|c|c|}
\hline Value For Money & \multicolumn{3}{|c|}{ Year } \\
\cline { 2 - 4 } & $\mathbf{2 0 1 7}$ & $\mathbf{2 0 1 8}$ & $\mathbf{2 0 1 9}$ \\
\hline Economical & $111 \%$ & $115 \%$ & $105 \%$ \\
& & & \\
\hline Efficiency & $104 \%$ & $99 \%$ & $99 \%$ \\
& & & \\
\hline Effectiveness & $90 \%$ & $89 \%$ & $100 \%$ \\
\hline
\end{tabular}

Table 1:- Measurement of Value for Money by the Government of North Nias Regency in 2017, 2018 and 2019

Source: Author, 2020

Based on table 1 above, it can be seen that the financial ratio in 2017 to 2019 in maintaining a certain quantity of resources has fluctuated. In 2017 the achievement level of $111 \%$ was said to be uneconomical. In 2018 the achievement level $115 \%$ was said to be uneconomical, and in 2019 the achievement level $105 \%$ is 
said to be uneconomical. In contrast, if an agency or organization is very economical, the percentage level of achievement is below $60 \%$. So, Kab. North Nias is said to be uneconomical because it cannot minimize the input resources used so that expenditure is unproductive or wasteful.

The efficiency ratio is 2017 to 2019 in the use of public funds must produce maximum output. In 2017 the achievement level of $104 \%$ was said to be inefficient. In 2018 the achievement level of $99 \%$ was ineffective, and in 2019 the achievement level of $99 \%$ is said to be weak. So, Kab. North Nias is said to be inefficient in using funds to produce maximum output.

The effectiveness ratio in 2017 to 2019 that the budget must reach the targets that have set. In 2017 the achievement level of $90 \%$ was said to be effective. In 2018 the achievement level of $89 \%$ was quite significant, and in 2019 the achievement level of $100 \%$ is said to be effective. So, North Nias Regency is said to be effective in achieving the targets and goals for the public interest that have been set each year but fluctuating.

The measurement of value for money to public accountability in implementing budget management and the implementation stage of public budgeting does not have access (low accountability). Regency. The terms of accountability of North Nias related to the consideration of the stated objectives, is not appropriate, as a result in the maintenance and use of resources in quantity and quality that are not optimal and wasteful or not economical and the accountability in making a policy does not consider the objectives and policies taken.

Based on the phenomena it shows that the condition of North Nias Regency has not succeeded in improving internal control, professionalism, and welfare of the apparatus, structuring regional apparatus institutions, increasing the strengthening of regional government capacity, increasing the accountability of local government performance, increasing accountability of regional financial management performance, availability of documents. Planning in all SKPD, increasing executive and legislative partnerships, and preventing the practice of KKN.

From the phenomenon, this study will examine the effect of financial report presentation, financial report accessibility, value for money, internal control, and leadership style on the accountability of regional financial management in North Nias Regency Government in particular, with the title "Analysis of Determinants. Accountability for Regional Financial Management in the Regional Government of North Nias Regency ".

\section{LITERATURE REVIEW}

\section{A. Financial Management Accountability}

Accountability can live and develop in a transparent and democratic atmosphere, and there is freedom in expressing opinions. With the control and fair leadership style, it hoped that it could increase regional financial management accountability. The realization of local financial accountability will be the initial basis for better governance. All financial accountability from public funds will run smoothly in line with public trust in government in regional financial management (Ludani et al. 2015).

\section{B. Presentation of Financial Statements}

The main factor in realizing accountability is the presentation of financial reports that are relevant, reliable, easy to understand, and accountable to the public. (Lewier, 2016). It means that the better the presentation of regional government financial reports, the better the realization of local financial management accountability.

\section{Accessibility of Financial Statements}

The accessibility of financial reports is ease for someone to obtain financial statement information. In-Law No. 33 of 2004 concerning Financial Balance between the Central Government and Regional Governments, article 103 states that the information in the regional financial information system (SIKD) is open data that can be accessed and obtained by the public. According to a spatial perspective, accessibility is the condition or availability of a connection from one place to another or the ease with which a person or vehicle can move from one place to another safely, comfortably, and at a reasonable speed. It means that local governments must open access to broad stakeholders to the financial reports they produce, for example, by publishing regional financial reports through newspapers, the internet, or other means.

\section{Value for Money}

Public accountability is not just the ability to show how public money has been spent but includes the ability to show how public money has been spent economically, efficiently, and effectively (Mardiasmo, 2004). Through value for cash, financial reporting can be measured and to be answered.

\section{E. Internal Control System}

Based on Government Regulation of the Republic of Indonesia Number 60 of 2008 concerning the Government Internal Control System, the internal control system is an integral process of actions and activities carried out continuously by the leadership. All employees to provide adequate confidence in the achievement of organizational goals through effective and efficient activities. , reliability of financial reporting, safeguarding of state assets, and compliance with laws and regulations. 
The internal control system application aims to prevent irregularities, waste, diversions, obstacles, mistakes, and failures in achieving goals and objectives and the implementation of organizational tasks as early as possible.

\section{F. Leadership Style}

Leadership style is a behavior norm used by a person when that person tries to influence others' behavior as he sees it (Thoha, 2007).

Efforts to create a clean and accountable bureaucracy can only be implemented if they have good leadership skills in improving services to the public.

\section{G. Framework}

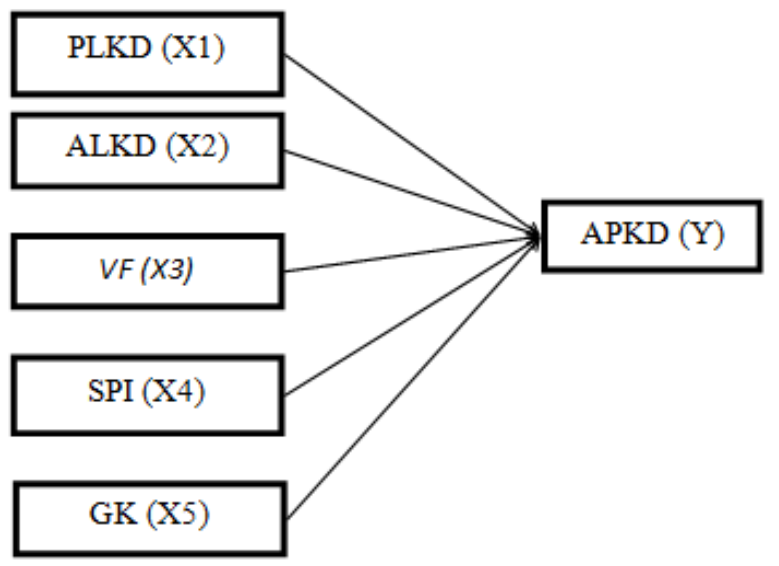

Fig 1

\section{H. Hypothesis}

H1: The presentation of financial statements has a positive effect on public accountability

$\mathrm{H} 2$ : Accessibility of financial reports has a positive effect on the accountability of regional financial management H3: Value for money has a positive effect on the accountability of local financial management

H4: Internal control system has a positive effect on the accountability of regional financial management

H5: The leadership style has a positive effect on the accountability of local financial management

\section{RESEARCH METHODOLOGY}

\section{A. Research Approach}

The design of this research is causal research. Umar (2008) states that the causal method is useful for analyzing how a variable affects other variables. It is also helpful in experimental research where the independent variable is treated in a controlled manner by the researcher to see its impact on the dependent variable directly. In this study, the method used is a survey research method. Field research was conducted on several sample members from a specific population whose data collection is carried out using a questionnaire.

\section{B. Data Analysis Methods}

In this study, the data analysis method used was structural equation modeling-partial least squares (SEMPLS) using the Smart-PLS 3.0 software.

\section{RESULT}

\section{A. Evaluasi Outer Model (Measurement Model)}

The outer model or measurement model describes the relationship between indicator blocks and their latent variables. This model relates explicitly latent variables to its indicators, or it can be said that the outer model defines how each indicator relates to other variables.

The Structural Equation Modeling (SEM) analysis results in this study can be seen in the following figure:

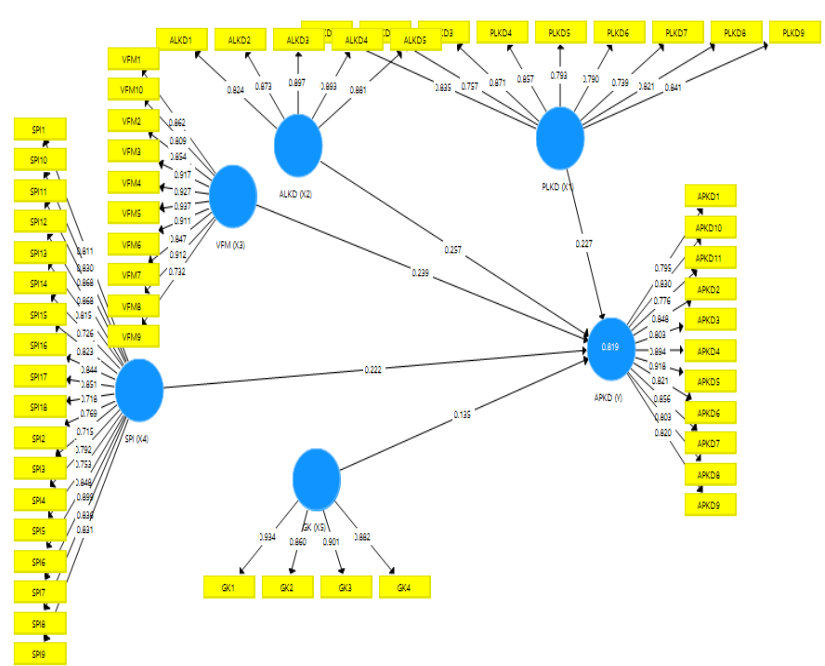

Fig 2:- Path Diagram based on Loading Factor Value

Based on testing the loading factor's validity in that figure, all loading values are $>0.7$, which means that the validity requirements are met based on the loading value.

\begin{tabular}{|c|c|}
\hline & Composite Reliability \\
\hline ALKD $(\mathrm{X} 2)$ & 0.942 \\
\hline APKD (Y) & 0.962 \\
\hline GK $(\mathrm{X} 5)$ & 0.941 \\
\hline PLKD $(\mathrm{X} 1)$ & 0.946 \\
\hline SPI $(\mathrm{X} 4)$ & 0.972 \\
\hline VFM (X3) & 0.970 \\
\hline
\end{tabular}

Table 2:- Reliability Testing based on Composite Reliability (CR)

It is known that all CR values are> 0.7, which means that they have met the reliability requirements based on CR.

\section{B. Evaluation of the Model Structure (Inner Model)}

$>$ Analysis of Variant (R2) or Determination Test

The structural model (inner model) is a structural model to predict the latent variables' causality relationship. 


\begin{tabular}{|c|c|}
\hline & R Square \\
\hline APKD $(\mathbf{Y})$ & 0.819 \\
\hline
\end{tabular}

Table 3:- Value coefficient of determination

The coefficient of determination for the regional financial management accountability variable is 0.819 , which means that the presentation of financial statements, financial report accessibility, value for money, internal control systems, leadership style can influence the accountability of regional financial management by $81.9 \%$.

\section{Significance Test of Direct Effect}

Hypothesis testing is conducted to determine the effect or absence of the independent variable on the dependent variable. The hypothesis is accepted if the prob (P) value $<0.05$. The partial hypothesis test results can be seen in the table below.

\begin{tabular}{|c|c|c|c|c|c|}
\hline & Original Sample $(\mathbf{O})$ & Sample Mean (M) & Standard Deviation (STDEV) & T Statistics (|O/STDEV|) & P Values \\
\hline$(\mathrm{X} 2)->(Y)$ & 0.257 & 0.240 & 0.100 & 2.576 & 0.010 \\
\hline (X1) -> (Y) & 0.227 & 0.247 & 0.115 & 1.964 & 0.050 \\
\hline (X3) -> (Y) & 0.239 & 0.226 & 0.075 & 3.199 & 0.001 \\
\hline
\end{tabular}

Table 4:- Path Coefficient Value and P-Value (Significance Test of Direct Effect)

Based on the table, the results obtained:

- The presentation of financial statements has a positive effect on regional financial management's accountability with a path coefficient of 0.227 . Still, it is not a significant p-value of 0.0500 .05 , and it is concluded that the presentation of financial statements does not affect regional financial management's accountability.

- Accessibility of financial reports has a positive effect on the accountability of regional financial management with a path coefficient of 0.257 and significant with a pvalue of $0.010<0.05$, it is concluded that financial report accessibility has a positive and significant effect on the accountability of regional financial management.

- Value for money has a positive effect on regional financial management's accountability with a path coefficient of 0.239 and significant with a p-value of $0.001<0.05$. It is concluded that value for money has a positive and significant effect on regional financial management's accountability.

- The internal control system has a positive effect on regional financial management's accountability with a path coefficient of 0.222 and significant, with a p-value of $0.023<0.05$. The internal control system has a positive and significant effect on the accountability of regional financial management.

- Leadership style positively affects the accountability of regional financial management with a path coefficient of 0.135 and significant with a p-value of $0.044<0.05$. Leadership style has a positive and significant effect on the accountability of regional financial management.

\section{CONCLUSION AND RECOMMENDATION}

\section{A. Conclusions}

The conclusion of this study through the SmartPLS 3.0 statistical test The effect of financial statement presentation, financial report accessibility, value for money, internal control systems, and leadership style on the accountability of regional financial management in North Nias Regency can be concluded in general that, financial statement accessibility, value for money, the internal control system and leadership style affect the accountability of regional financial management. Still, the presentation of financial reports does not affect the accountability of local financial management. Referring to these general conclusions, the specific findings in this study are:

$>$ The presentation of financial statements does not affect the accountability of regional financial management.

$>$ Accessibility has a significant effect on the accountability of local financial management.

$>$ Value for money has a significant effect on the accountability of regional financial management.

$>$ The internal control system has a significant effect on the accountability of local financial management.

$>$ The leadership style has a significant effect on the accountability of local financial management.

\section{B. Suggestions}

Based on the research that has been done, there are several suggestions that researchers can submit, including:

$>$ Further research needs to consider determining a broader research object with a provincial scope and increasing the number of research samples.

$>$ The results show that independent variables can contribute well to regional financial accountability but still need to be developed. For further researchers, it is recommended to consider the use of other variables that are broader than the variables studied in this study, for example, transparency, supervision, and apparatus competence, which can affect the accountability of regional financial management.

\section{REFERENCES}

[1]. Abdullah, J. (2018). Pengaruh Penerapan Dimensi Value For Money Terhadap Akuntabilitas Publik Pada Dinas Kesehatan Kabupaten Pohuwat. volume 1-No. 1 P-ISSN : 2614 -2074.

[2]. Amirullah. (2015). Metode Penelitian Manajemen. Malang: Bayumedia Publishing.

[3]. Ancok, D. (1998). Teknik Penyusunan Skala Pengukur. Yogyakarta: Gajah Mada University Press. 
[4]. Armando, G. (2013). Pengaruh Sistem Pengendalian Itern Pemerintah dan Pengawasan Keuangan Daerah Terhadap Nilai Informasi Laporan Keuangan Pemerintah (Studi Empiris pad Satuan Kerja Perangkat Daerah di Kota Bukittinggi). Jurnal akuntansi. Universitas Negeri Padang.

[5]. Arumanti, N. R. (2018). Aksesibilitas Laporan Keuangan Dan Penyajian Laporan Keuangan Terhadap Akuntabilitas Pengelolaan Keuangan Daerah Dengan Internal Controlsebagai Variabel Moderating (Studi Pada Pemerintah Kabupaten Gowa) . skripsi.

[6]. Bandariy, H. (2011). Pengaruh Penyajian Laporan Keuangan Daerah dan Aksesibilitas Laporan Keuangan Terhadap Penggunaan Informasi Keuangan Daerah. Skripsi Semarang Universitas Diponegoro.

[7]. Erlina, O. R. (2015). Akuntansi keuangan daerah. Edisi 4. Jakarta: salemba empat.

[8]. Fadli, A. (2004). Pengaruh Gaya Kepemimpinan terhadap Kinerja Karyawan pada PT. Kawasan Industri Medan. Tesis, Program Pasca Sarjana Universitas Sumatera Utara.

[9]. Fauziyah, M. R. (2017). Pengaruh Penyajian dan Aksesibilitas Laporan Keuangan Daerah Terhadap Akuntabilitas Pengelolaan Keuangan Daerah. Jurnal Riset dan Ilmu Akuntansi, Vol.6, No 6.STISEA Surabaya.

[10]. Fitri, Y. ( 2018.). Analysis Of Factors Affecting The Quality Of Government Financial Statements Of Binjai City With Work Motivation As Moderating Variables. Public Budgeting, Accounting, and Finance, ISSN 2655-6693.

[11]. Ghozali, I. (2013). Aplikasi Analisis Multivariate dengan Program IBM SPSS19. Semarang: Penerbit Universitas Diponegoro.

[12]. Ghozali, I. (2016). Aplikasi Analisis Multivariate Dengan Program IBM SPSS 23. semarang: Badan Penerbit Universitas Diponegoro.

[13]. Gio, P. U. (2015). Belajar Olah Data dengan SPSS, MINITAB, R, MICROSOFT EXCEL, EVIEWS, LISREL, AMOS, dan SMARTPLS,. USUPress.

[14]. Grosso, A. L. (2011). How Citizens View Government Performance Reporting. Public Performance \& Management Review, 35, 235-250.

[15]. Hapsari, N. ( 2018. ). The Influence Of Competence, Accountability, Motivation, And Organizational Commitment On The Performance Of Regional Financial Managers In Skpds (Regional Work Units) Of Binjai Municipal Administration. International Journal of Public Bud, ISSN 2655-6693.

[16]. Hartono, J. (2011). Konsep dan Aplikasi Struktural Equation Modeling Berbasis Varian Dalam Penelitian Bisnis. Yogyakarta: UPP STIM YKPN.

[17]. Hehanussa, S. J. (2015). Pengaruh Penyajian Laporan Keuangan Daerah dan Aksesibilitas Laporan Keuangan Daerah Terhadap Transparansi dan Akuntabilitas Pengelolaan Keuangan Daerah Kota Ambon. Jurnal Ekonomi, Vol 2,No 1.Universitas Sultan Agung.
[18]. Herawati, A. F. (2011). Analisis Value For Money Dalam Meningkatkan Mutu Pelayanan Publik Pada Stasiun Kereta Api Surabaya Kota.

[19]. Ichlas, M. H. (2014). Pengaruh Penerapan Standar Akuntansi Pemerintahan, Sistem Pengendalian Intern Pemerintah dan Aksesibilitas Laporan Keuangan Terhadap Akuntabilitas Keuangan Pemerintah Kota Banda Aceh. Jurnal Magister Akuntansi, Pascasarjana Universitas Syiah Kuala.

[20]. Indra Gunawan, S. (2018.). Analysis Of Factors Affecting Managerial Performance Skpd In North Sumatera Provincial Government With Internal Control AS Moderating Variables. International Journal of Public Budgeting, Accounting, and Finance, ISSN 2655-6693.

[21]. Indriaswari, L. K. (2017). Analisis Value For Moneydalam Pengukuran Kinerja pada Dinas Pertanian Perkebunan dan Kehutanan Kabupaten Banyumas Periode Tahun. Skripsi Yogyakarta. Universitas Sanata Dharma Yogyakarta.

[22]. Judith, H. M. (2009). Building Trust or Mistrust: The Search for Performance Reporting from a Citizen's Perspective. The Journal of Government Financial Management, Winter, 40-46.

[23]. Krismiaji. (2010). Sistem Informasi Akuntansi Edisi tiga. Yogyakarta: AMP YKPN.

[24]. Krisnayanti, I. A. (2013). Analisis Persepsi Stakeholder Internal dan eksternal Terhadap Transparansi dan Akuntabilitas Laporan Keuangan Pengelolaan Dana BOS di SMP Negeri 1 Banjar . Universitas Pendidikan Ganesha .

[25]. Kurniawati, M. M. (2016). Pengaruh Penyajian Laporan Keuangan Daerah, Aksesibilitas Laporan Keuangan Daerah, dan Sistem Akuntansi Keuangan Daerah Terhadap Transparansi dan Akuntabilitas Pengelolaan Keuangan Daerah (Studi pada Satuan Kerja Perangkat Daerah Kabupaten Jember). Jurnal Akuntansi, Universitas Jember.

[26]. Lewier, C. N. (2016). Pengaruh Penyajian Laporan Keuangan Daerah dan Aksesibilitas Laporan Keuangan Daerah Terhadap Akuntabilitas Pengelolaan Keuangan Daerah Kabupaten Klaten. Skripsi:Yogyakarta: Universitas Atma Jaya Yogyakarta.

[27]. Liando, H. S. (2014). Analisis Kinerja Keuangan Pemerintah Kabupaten Kepulauan Sangihe Menggunakan Metode Value For Money. Jurnal EMBA, Vol.2 No.3. Universitas Samratulangi Manado.

[28]. Ludani, M. M. (2015). Akuntabilitas Dalam Pengelolaan Keuangan Daerah (Suatu Studi Pada Dinas Pendapatan Daerah Kabupaten Banggai Kepulauan). Accounting Journal.

[29]. Mahmudi. (2010). Analisis Laporan Keuangan Pemerintah Daerah Edisi Kedua. Yogyakarta: UPP STIM YKPN.

[30]. Mahmudi. (2011). Akuntansi Sektor Publik. Yogyakarta: UII Press. 
[31]. Mustafa, A. I. (2012). Pengaruh Penyajian dan Aksesibilitas Laporan Keuangan terhadap Akuntabilitas Pengelolaan Keuangan Kabupaten Pemalang. Journal Unnes.ac.id.

[32]. Nordiawan, D. (2006). Akuntansi Sektor Publik. Jakarta: Salemba Empat.

[33]. Nordiawan, D. (2010). Akuntansi Sektor Publik. Jakarta: Salemba Empat.

[34]. Nugraha, D. S. (2010). The Influence of Internal Control System to The Reliability of Local Government Financial Statement (Case Study at Pemerintah Provinsi Jawa Barat),. Jurnal Ekonomi,keuangan, perbankan, akuntansi, Vol. 2 No. 2.

[35]. Nugraha, D. S. (2011). Pengaruh Sistem Pengendalian Intern Terhadap Transparansi dan Akuntabilitas Aset Tetap Pemerintah (Studi Kasus pada Pemerintah Kota Cimahi). Jurnal Sigma-Mu, Vol. 3 No.1.

[36]. Nurmuthmainnah, W. (2015). Pengaruh Penyajian Laporan Keuangan Daerah dan Aksesibilitas Laporan Keuangan Daerah terhadap Akuntabilitas Pengelolaan Keuangan Daerah Kabupaten Konawe Utara. Skripsi. Makassar:, akultas Ekonomi dan Bisnis Universitas Hasanuddin Makassar.

[37]. Pasaribu, F. (2011). Pengaruh Penyajian Laporan Keuangan SKPD Dan Aksesibilitas Laporan Keuangan SKPD Terhadap Transparansi Dan Akuntabilitas Pengelolaan Keuangan SKPD. Tesis, Medan. Program Pasca Sarjana Universitas Sumatera Utara.

[38]. Pramudita, A. (2017). Pengaruh Penerapan Standar Akuntansi Pemerintah Value For Money dan Sistem Pengendalian Intern Terhadap Akuntabilitas Pengelolaan Keuangan Daerah (Studi Empiris pada Organisasi Pemerintah Daerah (OPD) Kabupaten Ponorogo. Skripsi., Universitas Muhammadiyah Ponorogo.

[39]. Primayani, P. R. (2014). Pengaruh Pengendalian Internal Value For Money Penyajian Laporan Keuangan dan Aksesibilitas Laporan Keuangan Terhadap Akuntabilitas Pengelolaan Keuangan (Studi Empiris Pada SKPD di Pemerintahan Daerah Kabupaten Klungkung). E-Jurnal S1 Ak Vol.2, No.1., Universitas Pendidikan Ganesha.

[40]. Purbasari, H. d. (2017). Pengaruh Desentralisasi Fiskal, Sistem Pengendalian Internal dan Kinerja Pemerintah Daerah Terhadap Akuntabilitas Laporan Keuangan. Jurnal Fakultas Ekonomi dan Bisnis, Universitas Muhammadiyah Surakarta.

[41]. Ramon, D. (2014). Pengaruh Sistem Pengendalian Intern Terhadap Akuntabilitas Keuangan (Studi Empiris Pada Inspektorat Kota Se Provinsi Sumatera Barat). Jurnal Akuntansi Fakultas Ekonomi, Universitas Bung Hatta.

[42]. Republik, I. (n.d.). Instruksi Presiden (Inpres) nomor 71999 tentang Laporan Akuntabilitas Kinerja Instansi Pemerintah.

[43]. Republik, I. (n.d.). Undang-Undang no. 28 Tahun 1999 tentang Penyelenggaraan Negara yang Bebas dari Korupsi, Kolusi, dan Nepotisme.
[44]. Retno. (2010). Analisis Faktor-Faktor Yang Mempengaruhi Kualitas Laporan Pertanggungjawaban Di Satker Universitas Negeri Medan. Tesis, Sekolah Pasca Sarjana Universitas Sumatra Utara.

[45]. Sanjaya, D. N. (2014). Pengaruh Penyajian Laporan Keuangan Daerah, Sumber Daya Manusia, Pengendalian Internal dan Aksesbilias Laporan Keuangan terhadap Penggunaan Laporan Keuangan Daerah (Studi Kasus pada SKPD diKabupaten Buleleng),. e-Journal Vol 2 No 1 S1.Ak., Universitas Pendidik (Ganesha Jurusan Akuntansi Program S1).

[46]. Santoso, E. B. (2016). Pengaruh Sistem Pengendalian Intern Pemerintah, Pemanfaatan Teknologi Informasi dan Kompetensi Sumber Daya Manusia Terhadap Akuntabilitas Keuangan Daerah (Studi Empiris pada Pemerintah Kabupaten Lampung Timur). Tesis., Bandar Lampung. Universitas Lampung.

[47]. Sari, E. W. (2017). Pengaruh Sistem Pengendalian Intern, Penyajian Laporan Keuangan, Aksesibilitas Laporan Keuangan dan Gaya Kepemimpinan Terhadap Transparansi dan Akuntabilitas Pengelolaan Keuangan Daerah di Kabupaten Indragiri Hulu. urnal Fakultas Ekonomi, Universitas Riau.

[48]. Sayuti. (2018). Perwujudan Nilai-Nilai Transparansi, Akuntabilitas dan Konsep Value For Money dalam Pengelolaan Akuntansi Keuangan Sektor Publik pada Bappeda Kabupaten Gowa. Skripsi. , Makassar. Universitas Islam Negeri Alauddin Makassar.

[49]. somad, a. (2016). Pengaruh Penyajian Laporan Keuangan Daerah dan Aksesibilitas Laporan Keuangan Daerah Terhadap Akuntabilitas Pengelolaan Keuangan Daerah. Journal Riset Mahasiswa Akuntansi (JRMA).

[50]. Stecolini, I. (2002). Local government annual Report: an Accountability Medium?. Paper Dipresentasikan Pada EIASM Conference on Accounting and Auditing in Public Sector Performs, Durbin.

[51]. Subekti, I. A. (2015). “ Pengaruh Kualitas Penyajian Laporan. JSAI, Vol. 2 No. 1 Juni 2015. Hlm. 72-84.

[52]. Sugiyono. (2010). Metode Penelitian Kuantitatif, dan Kualitatif dan $R \& D$. Bandung.

[53]. Sugiyono, A. (2013). Metode Penelitian bisnis. Bandung: Alfabeta.

[54]. Superdi. (2017). Pengaruh Penyajian Laporan Keuangan, Aksesibilitas Dan Sistem Akuntansi Keuangan Daerah Terhadap Akuntabilitas Pengelolaan Keuangan Daerah (Studi Empiris pada Satuan Kerja Pemerintah Daerah Kabupaten Sijunjung). Jurnal Fakultas Ekonomi, Universitas Riau.

[55]. VERONICA, J. S. (2018). ANALYSIS OF FACTORS AFFECTING WEAKNESSES OF INTERNAL CONTROL SYSTEM AT DISTRICT AND CITY GOVERNMENTS IN NORTH SUMATRA PROVINCE. International Journal of Public Budgeting, Accounting, and Finance, ISSN 2655-6693. 
[56]. Wahyuni, P. S. (2014). Pengaruh Penyajian Laporan Keuangan Daerah dan Aksesibilitas Laporan Keuangan Daerah Terhadap Akuntabilitas Pengelolaan Keuangan Daerah (Studi Empiris pada Pemerintahan Kabupaten Badung). E-Journal S1 Ak, Universitas Pendidikan Ganesha.

[57]. Wardana, I. (2016). Akuntabilitas dalam Pengelolaan Keuangan Desa (Studi pada Pemerintah Desa di Kabupaten Magelang. Skripsi, Semarang. Universitas Negeri Semarang.

[58]. Zahro, F. H. (2018). Factors Affecting The Quality Of The Performance Accountability Report Of Government Agency With Organizational Commitments As A Moderating Variable Within Technical Implementation Units Of Directorate General Of Early Childhood Ed. International Journal of Public Budgeting, Accounting, and Finance, ISSN 2655-6693. 